\title{
Effects of Neurotensin and LANT-6 on Food Intake in Chicks
}

\author{
Keiko Masuda ${ }^{1}$, Eiko Iwakoshi-Ukena ${ }^{1}$, Tetsuya Tachibana ${ }^{2}$, Kazuyoshi Ukena $^{1,}$, \\ ${ }^{1}$ Graduate School of Integrated Arts and Sciences, Hiroshima University, Higashi-Hiroshima, Japan \\ ${ }^{2}$ Faculty of Agriculture, Department of Agrobiological Science, Ehime University, Matsuyama, Japan
}

\section{Email address:}

ukena@hiroshima-u.ac.jp (K. Ukena)

\section{To cite this article:}

Keiko Masuda, Eiko Iwakoshi-Ukena, Tetsuya Tachibana, Kazuyoshi Ukena. Effects of Neurotensin and LANT-6 on Food Intake in Chicks. American Journal of Life Sciences. Special Issue: Biology and Medicine of Peptide and Steroid Hormones. Vol. 3, No. 3-2, 2015 , pp. 17-23. doi: 10.11648/j.ajls.s.2015030302.14

\begin{abstract}
Neurotensin (NT) and an NT-related peptide (Lys, Asn, NT ${ }^{8-13}$; LANT-6) are produced in the chicken brain and intestine, and these peptides are encoded by the same precursor gene (NT/LANT-6 precursor). Although it has been reported that the central administration of NT suppresses food intake in mammals, the effect of NT and LANT-6 on feeding behavior in birds has not yet been investigated. In this paper, we analyzed the expression levels of NT/LANT-6 precursor and the NT receptor (NTR1) mRNAs in the hypothalamic infundibulum, an important region for regulating feeding behaviors. We also examined the effects of NT and LANT-6 administration on food intake in chicks. Real-time PCR analysis showed that NT/LANT-6 precursor and NTR1 mRNAs had moderately high expression in the hypothalamic infundibulum. Further, in the hypothalamic infundibulum, the mRNA level of NT/LANT-6 precursor showed a trend toward increasing during postnatal development and increased 2.9-fold after a 48 hour fast, although the NTR1 mRNA level was not changed in both analyses. Contrary to our expectations, central administration of NT or LANT-6 had no effect on food intake in chicks.
\end{abstract}

Keywords: Brain, Chicken, Food Intake, Hypothalamic Infundibulum, LANT-6, mRNA, Neurotensin

\section{Introduction}

Neurotensin (NT) is a 13 -amino-acid peptide first isolated from the bovine hypothalamus [1]. An NT-related 6-amino-acid peptide has also been isolated from porcine spinal cord, named neuromedin N (NMN) [2]. NT and NMN have an identical amino acid sequence of Pro-Tyr-Ile-Leu at the C-terminus and are encoded by the same precursor gene [3]. There are 3 types of NT receptors (NTR1, NTR2, and NTR3/sortilin) in mammals [4-7], and NT has the highest affinity to NTR1. NT and NMN are found in the brain and the gastrointestinal tract, where they contribute to a number of functions in mammals. In gastrointestinal tract, NT is involved in digestion, gut motility, intestinal neuroinflammation, and regeneration [8]. In the central nervous system, NT participates in hypothermia, antinociception, dopamine neurotransmission, and anterior pituitary hormone secretion [9]. Furthermore, it has been demonstrated that the central administration of NT reduces food intake in rats [10-12].

In avian species, NT and an NT-related 6-amino-acid peptide corresponding to mammalian NMN (Lys, Asn, $\mathrm{NT}^{8-13}$; LANT-6) have been purified from chicken intestine $[13,14]$. NT and LANT-6 also have an identical 4-amino acid sequence at the $\mathrm{C}$-terminus and are encoded by the same precursor gene as in mammals [15]. Figure 1 shows the amino acid sequence of the chicken NT/LANT-6 precursor protein. With regard to the receptors, only NTR1 has been characterized from chicken intestine [16].

We have recently identified NT and LANT-6 in the chicken brain and used in situ hybridization to reveal that the NT/LANT-6 precursor mRNA-expressing cells were mainly located in the telencephalon, which contains the nidopallium, hyperpallium, and hippocampus; and the hypothalamic infundibulum, which contains the infundibular nucleus and medial mammillary nucleus [17]. Above all, the hypothalamic infundibulum is known to be involved in regulation of food intake, and the avian infundibular nucleus corresponds to the mammalian arcuate nucleus. For instance, neuropeptide Y (NPY) is an orexigenic peptide expressed in the arcuate nucleus in mammals [18]. In the avian hypothalamus, NPY is expressed in the infundibular nucleus [19] and acts to potently increase food intake [20-22]. As 
described above, the central administration of NT inhibits food intake in rats [10-12]. These facts suggest that NT and LANT-6 may also regulate feeding behavior in birds.

In this study, we first quantified the expression of NT/LANT-6 precursor and NTR1 mRNAs in the hypothalamic infundibulum of the chick brain. Then, we analyzed changes in each mRNA expression during postnatal development and after fasting. Furthermore, effects of NT and LANT-6 on food intake were investigated.

\section{MRAQLVCVVLLALASCSLCSDSEEEMKALEADLLTNMYTSKMNRAKLSYWKVTLL 55 Signal peptide \\ 56 NVCNLINNMNNQVGETVEVDDEDLISGRQFPAALDGFSLEAMLTVYQLQKVCHSR 110 \\ 111 AFQHWELLQQDAFDLENSSQEKE IMKRKNPYILKRQLHVNKARRPYILKRSSYY 164}

Figure 1. Amino acid sequence of chicken NT/LANT-6 precursor protein (NP_001264289). Signal peptide, NT, and LANT-6 are underlined and processing sites are indicated by boldface.

\section{Materials and Methods}

\subsection{Animals}

Male layer chicks (Gallus gallus domesticus) were purchased from a commercial company (Nihon-Layer, Gifu, Japan).

For molecular biological analysis, chicks were kept in a room at $28^{\circ} \mathrm{C}$ with continuous lighting and were given food and tap water ad libitum. The experimental protocol was performed in accordance with the Guide for the Care and Use of Laboratory Animals prepared by Hiroshima University (Higashi-Hiroshima, Japan).

For behavioral studies, chicks were kept in a room at $30^{\circ} \mathrm{C}$ with continuous lighting and were given commercial diet (crumble, crude protein: 24\%, metabolizable energy: 3,050 kcal/kg; Toyohashi Feed Mills, Aichi, Japan) and tap water ad libitum. Chicks were placed in individual cages 1 day prior to each experiment. They were weighed and divided into experimental groups as uniformly as possible for each treatment. Chicks were maintained in accordance with the recommendations of the National Research Council [23]. The experimental protocol was approved by the Committee of Animal Care and Use in Ehime University (Ehime, Japan).

\section{2. $R N A$ and $c D N A$ Preparation}

Chicks were killed by decapitation. The telencephalon, diencephalon, hypothalamic infundibulum, optic tectum, pons and medulla oblongata, and cerebellum were dissected, snap-frozen in liquid nitrogen, and used for RNA isolation. RNA from the chick brain was extracted using a TRIzol reagent or an RNAqueous-Micro kit (Life Technologies, Carlsbad, CA) in accordance with the manufacturer's instructions.

The first strand of cDNA was synthesized from RNA prepared from each brain regions using a ReverTra Ace qPCR RT Kit Master Mix with gDNA Remover (TOYOBO, Osaka, Japan) in accordance with the manufacturer's instructions.

\subsection{Real-Time PCR}

To analyze the expression levels of NT/LANT-6 precursor and NTR1 mRNAs, the cDNA prepared from each brain region was amplified. PCR amplifications were carried out with the THUNDERBIRD SYBR qPCR Mix (TOYOBO) using the following program: $95^{\circ} \mathrm{C}$ for $20 \mathrm{sec}, 40$ cycles at $95^{\circ} \mathrm{C}$ for $3 \mathrm{sec}$, and at $60^{\circ} \mathrm{C}$ for $30 \mathrm{sec}$. The PCR products in each cycle were monitored using a real-time thermal cycler (StepOne; Life Technologies). The each level of mRNA expression was normalized to the level of $\beta$-actin (ACTB) mRNA. The nucleotide sequences of primers for the amplification are shown in Table 1.

Table 1. Nucleotide sequence of primers.

\begin{tabular}{|c|c|}
\hline Target gene & Primer sequences (5' to 3') \\
\hline \multirow{2}{*}{ NT/LANT-6 precursor } & Forward: CATTTCTGGAAGACAGTTCC \\
\hline & Reverse: GCGTCTTGCTGAAGTAACTC \\
\hline \multirow{2}{*}{ NTR1 } & Forward: TTTGCTACGTCCCCTCCAAC \\
\hline & Reverse: ATGGGGTTGATTGCCGAACT \\
\hline \multirow[t]{2}{*}{$\beta$-actin (АCTB) } & Forward: AGCCAACAGAGAGAAGATGA \\
\hline & Reverse: CCAGAGTCCATCACAATACC \\
\hline
\end{tabular}

\subsection{Peptide Preparation}

NT and LANT-6 were synthesized by Fmoc solid-phase peptide synthesis using a peptide synthesizer, Syro Wave (Biotage, Uppsala, Sweden). The peptides were purified by reverse-phase high-performance liquid chromatography (HPLC) using a C18 column (YMC-Pack Pro C18, 10×150 $\mathrm{mm}$; YMC, Kyoto, Japan). The collected peaks were evaporated and lyophilized. Synthetic peptides were confirmed by matrix-assisted laser desorption-ionization time-of-flight mass spectrometry (MALDI-TOF-MS) analysis on AXIMA-CFR plus (Shimadzu, Kyoto, Japan).

The synthetic NT and LANT-6 were dissolved in a saline solution containing $0.1 \%$ Evans blue dye, which included $0.005 \mathrm{~N} \mathrm{HCl}$ to support the dissolution of peptides. This vehicle was used for the control treatment.

\subsection{Intracerebroventricular (ICV) Injections}

Six-day-old chicks were injected ICV with NT or LANT-6. All injections were given between 8:00 and 10:00 a.m. and performed according to a previously reported method [24]. In brief, the head of the chick was inserted into an acrylic box with a hole in the top plate. The injection coordinates 
targeting the left lateral ventricle were $3 \mathrm{~mm}$ anterior from the parietal bone, $1 \mathrm{~mm}$ lateral from the sagittal suture, and 3 $\mathrm{mm}$ deep. Anatomical landmarks were determined visually and by palpation. The peptide solution was injected through the hole using a micro-syringe at a volume of $10 \mu \mathrm{l}$. This procedure is quick and does not stress the neonatal chicks judging from food intake and corticosterone release $[25,26]$. At the end of each experiment, the chicks were euthanized with an overdose of pentobarbital. The brain was then removed to confirm the accuracy of injection. Any chicks in which Evans blue dye could not be defined in the lateral ventricle were not used for further analyses.

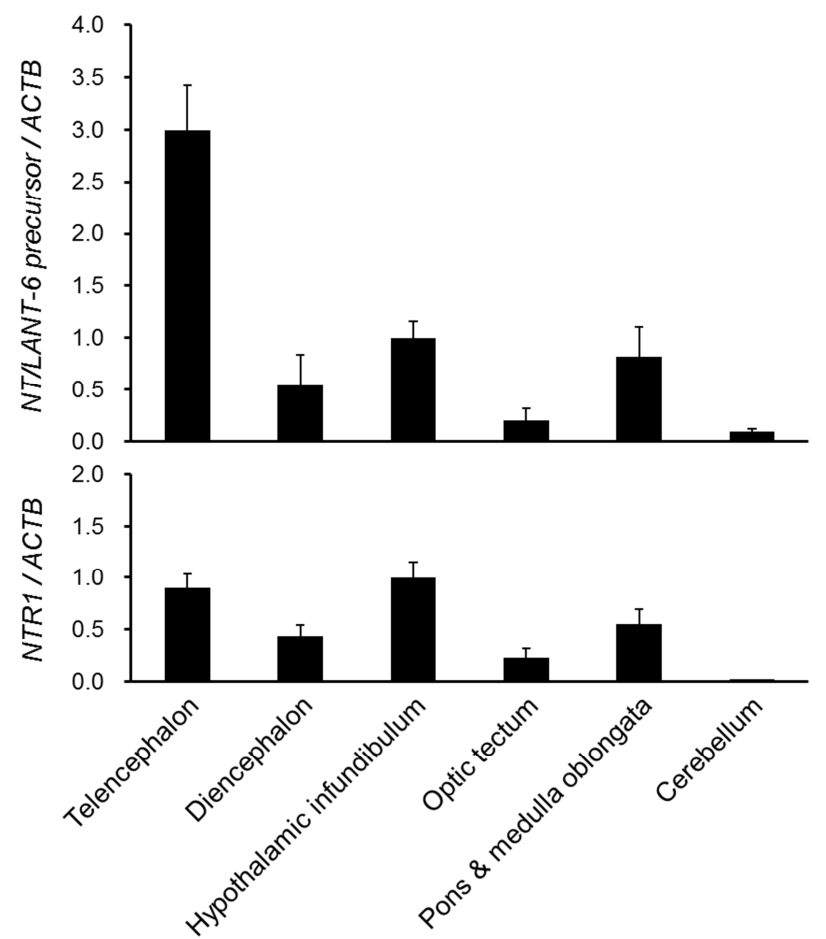

Figure 2. Expression levels of NT/LANT-6 precursor and NTR1 mRNAs in each brain region of 1-day-old chicks $(n=4-6)$. Each value represents mean $\pm S E M$.

A
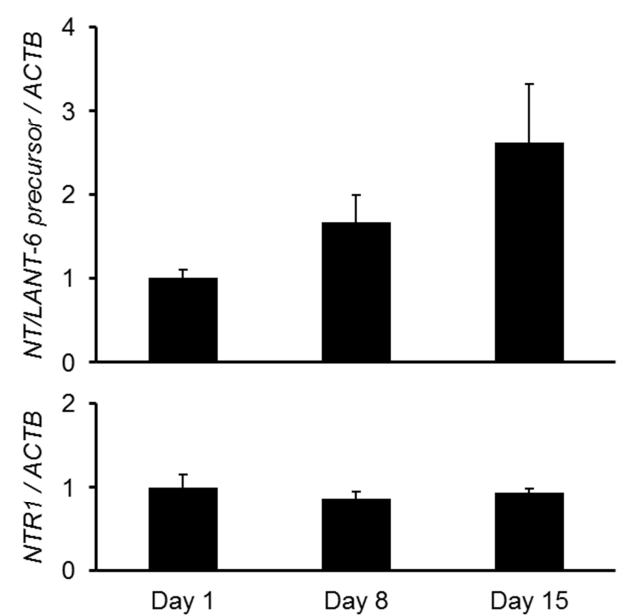

\subsection{Measurement of Food Intake}

Food intake was measured under ad libitum feeding conditions. A pre-weighed feeder was given to each chick, and food intake was measured at 30,60, and 90 min after the injection using a digital balance with an accuracy of $1 \mathrm{mg}$.

\subsection{Statistical Analysis}

Data were analyzed with Student's t-test or two-way analysis of variance (ANOVA) followed by the Tukey-Kramer test as a post hoc test. The significance level was set at $\mathrm{P}<0.05$. All results are expressed as the mean \pm SEM. The numbers of chicks for each experiment are noted in the figure legends.

\section{Results}

\subsection{Expression of NT/LANT-6 Precursor $m$ RNA}

The expression levels of NT/LANT-6 precursor and NTR1 mRNAs in the following brain regions of 1-day-old chicks were examined by real-time PCR: the telencephalon, the diencephalon, the hypothalamic infundibulum, the optic tectum, the pons and medulla oblongata, and the cerebellum. The expression level of NT/LANT-6 precursor mRNA was highest in the telencephalon, followed by the hypothalamic infundibulum, and lowest in the cerebellum, whereas the expression level of NTR1 mRNA was highest in the hypothalamic infundibulum and below measurable limits in the cerebellum (Fig. 2).

Furthermore, changes in each mRNA expression in the hypothalamic infundibulum were examined. During postnatal development at days 1,8 , and 15, the expression level of NT/LANT-6 precursor mRNA showed a trend toward increasing (Fig. 3A). In 7-day-old chicks, the NT/LANT-6 precursor mRNA level was increased 2.9-fold after 48-hour fasting (Fig. 3B). On the other hand, the NTR1 mRNA level was not changed in both analyses (Fig. 3)

B
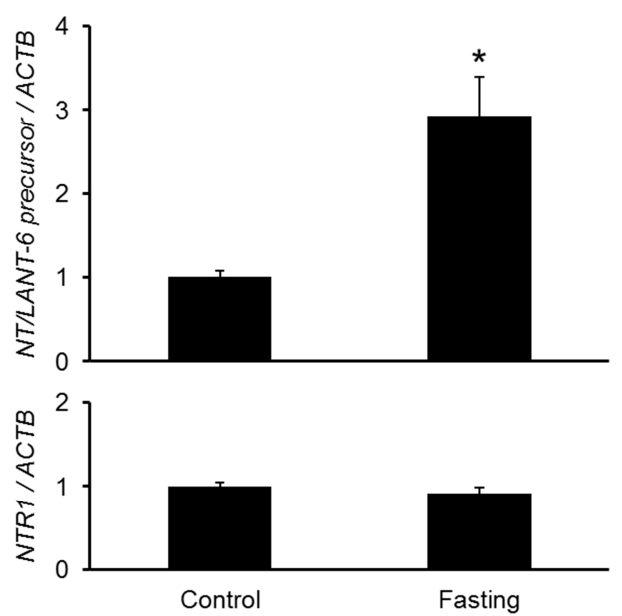

Figure 3. Expression levels of NT/LANT-6 precursor and NTR1 mRNAs in the hypothalamic infundibulum. (A) Changes in the level of mRNA expression during postnatal development $(n=4-6)$. (B) Changes in the level of mRNA expression after a 48 hour fast in 7-day-old chicks $(n=6-8)$. Each value represents mean \pm SEM. An asterisk indicates a statistically significant difference $(P<0.05)$. 
$\underline{\text { NT }}$

A

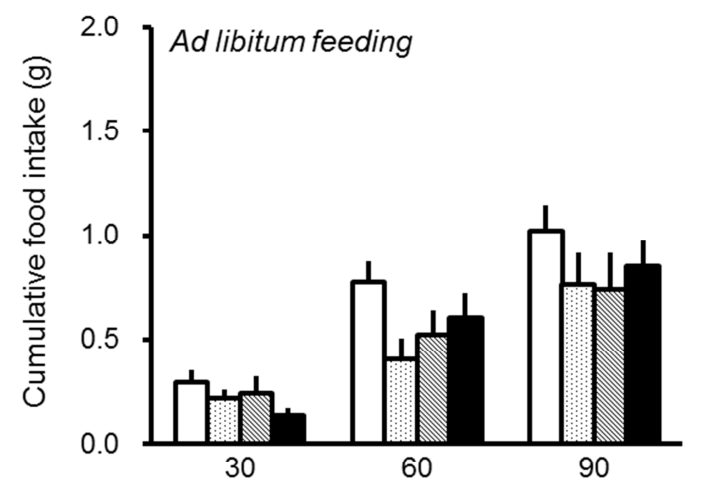

B

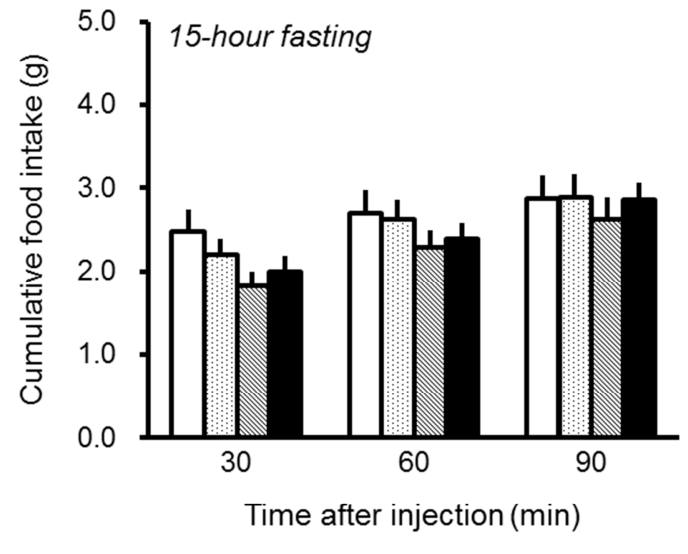

$0 \mathrm{nmol}$
$0.04 \mathrm{nmol}$ $0.2 \mathrm{nmol}$

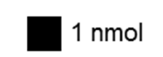

C

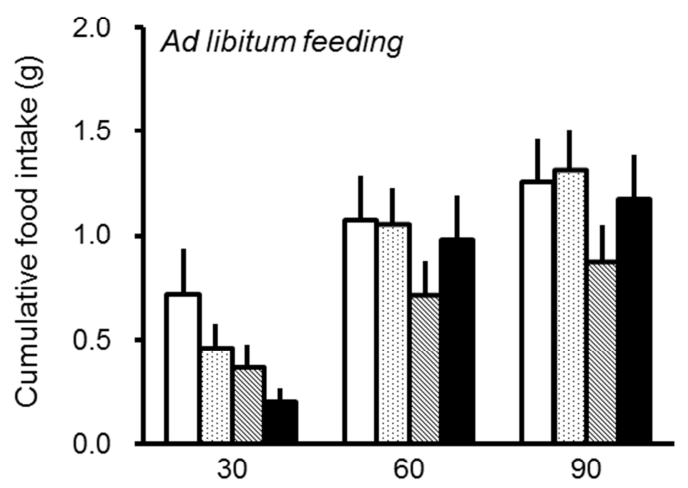

D

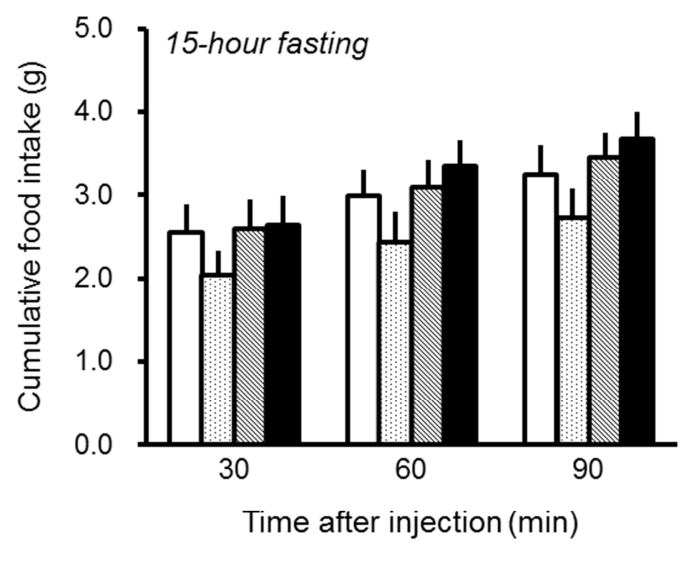

$\square 0 \mathrm{nmol} \quad 0.08 \mathrm{nmol} \mathbb{W} 0.4 \mathrm{nmol}$

$2 \mathrm{nmol}$

Figure 4. Effects of ICV injection of NT or LANT-6 on food intake. Six-day-old chicks were injected with NT (A and B) and LANT-6 (C and D) under ad libitum feeding $(A$ and $C)$ or 15-hour fasting conditions ( $B$ and $D)$, respectively. Each value represents mean $\pm S E M(n=6-10)$.

\subsection{Effects of NT and LANT-6 on Food Intake}

ICV injection of either NT (Figs. 4A and B) or LANT-6 (Figs. 4C and D) had no effect on food intake under either $a d$ libitum feeding (Figs. 4A and C) or 15-hour fasting (Figs. 4B and D) conditions in 6-day-old chicks.

\section{Discussion}

In the hypothalamic infundibulum, an important region for regulating feeding behaviors, the expression levels of NT/LANT-6 precursor and NTR1 mRNAs were moderately high. Furthermore, the expression level of NT/LANT-6 precursor mRNA was increased 2.9-fold after 48-hour fasting.

Despite the anorexigenic effect of NT in mammals, neither NT nor LANT-6 had an effect on food intake in chicks. It has been reported that the reduction of food intake induced by ICV injection of NT is greater in rats after fasting than after feeding ad libitum [12]. However, in chicks NT and LANT-6 had no effect on food intake even under the fasting condition. The required dose of NT to suppress feeding was $2 \mathrm{nmol}$ in rats and $0.1 \mathrm{nmol}$ in mice under fasting conditions [10,27]. In general, most bioactive substances take effect at lower doses in chicks than in rats. Thus, the doses of NT (up to $1 \mathrm{nmol}$ ) and LANT-6 (up to $2 \mathrm{nmol}$ ) used in this study would seem to be sufficient. Although we tested a higher dose of LANT-6 (10 nmol) in ad libitum feeding conditions since LANT-6 was shown to be 10 times less potent than NT on the colon contraction [17], food intake still did not change (data not shown).

The mechanisms for central regulation of food intake are slightly different between mammals and chicks [28]. For example, growth hormone-releasing hormone (GHRH) facilitates feeding behavior in mammals [29,30] but suppresses feeding in chicks [31]. In contrast, prolactin-releasing peptide (PrRP) suppresses feeding behavior in rats [32,33] but increases feeding in chicks [34]. These results suggest that the effects of NT on food intake in chicks are also different from those observed in mammals.

Leptin is an anorexigenic peptide found in mammals [35]. NT neurons in the hypothalamus express leptin receptors [36], and ICV injection of leptin has been shown to increase gene expression of hypothalamic NT in rats [37]. Furthermore, leptin induced feeding suppression was blocked by prior administration of NT antiserum or NT receptor antagonist in rats [38]. These data suggest that there is a close relationship between leptin and NT in mammals. Recently, leptin has been identified in avian species such as peregrine falcon [39], rock dove [40], and zebra finch [41]. In the chicken, although 
leptin has not yet been identified, there are several reports concerning effects of leptin on feeding behavior. Central administration of leptin decreased food intake in 4 or 7 week old chickens [42] but had no effect on feeding in 2-day-old chicks [43]. These results indicated that the responsiveness to the same substance could change with age. Leptin could suppress feeding by acting through NT release, which would explain why it has no effect in chicks. This study showed that the expression level of NT/LANT-6 precursor mRNA in the hypothalamic infundibulum tended to increase during postnatal development. Therefore, it is possible that NT could still decrease food intake in older chickens.

On the other hand, there are several reports suggesting a relationship between NT and histamine. Histamine decreases food intake in rats [44], and the effect is mainly mediated by activation of the histamine $\mathrm{H}_{1}$ receptor in the brain [45]. Furthermore, the anorexigenic effect of NT is partially blocked by treatment with a $\mathrm{H}_{1}$ receptor antagonist or by knockout of the $\mathrm{H}_{1}$ receptor in mice [27]. In chicks, histamine is expressed in the medial mammillary nucleus of the hypothalamic infundibulum [46], and ICV injection of histamine decreases food intake [46,47], whereas in this study NT had no effect on food intake. These results suggest that the relationship between NT and histamine in avian species is different from that observed in mammals.

\section{Conclusion}

NT/LANT-6 precursor and NTR1 mRNAs were expressed at a moderately high level in the hypothalamic infundibulum. Within this region, the expression level of NT/LANT-6 precursor mRNA showed a trend toward increasing during postnatal development and increased 2.9-fold after 48-hour fast, although NTR1 mRNA level was not changed in both analyses. In contrast to the anorexigenic effect of NT in mammals, ICV injection of NT and LANT-6 had no effect on chick food intake. To develop a better understanding about the effects of NT and LANT-6 on chicken feeding behavior, further study with older chickens will be required.

\section{Acknowledgments}

The mass spectrometry was performed using AXIMA-CFR plus at the Natural Science Center for Basic Research and Development (N-BARD), Hiroshima University. This work was supported by MEXT/JSPS KAKENHI grants (22687004 and 26291066 to K.U. and 25440171 to E.I.-U), Grant-in-Aid for JSPS Fellows (to K.M.), the Kieikai Research Foundation (K.U.), and the Program for Promotion of Basic and Applied Researches for Innovations in Bio-oriented Industry (K.U.).

\section{References}

[1] Carraway R, Leeman SE, "The isolation of a new hypotensive peptide, neurotensin, from bovine hypothalami," J Biol Chem, 1973, 248, pp. 6854-6861.
[2] Minamino N, Kangawa K, Matsuo H, "Neuromedin N: a novel neurotensin-like peptide identified in porcine spinal cord," Biochem Biophys Res Commun, 1984, 122, pp. 542-549.

[3] Dobner PR, Barber DL, Villa-Komaroff L, McKiernan C, "Cloning and sequence analysis of cDNA for the canine neurotensin/neuromedin N precursor," Proc Natl Acad Sci U S A, 1987, 84, pp. 3516-3520.

[4] Tanaka K, Masu M, Nakanishi S, "Structure and functional expression of the cloned rat neurotensin receptor," Neuron, 1990, 4, pp. 847-854.

[5] Chalon P, Vita N, Kaghad M, Guillemot M, Bonnin J, Delpech B, Le Fur G, Ferrara P, Caput D, "Molecular cloning of a levocabastine-sensitive neurotensin binding site," FEBS Lett, 1996, 386, pp. 91-94.

[6] Mazella J, Botto JM, Guillemare E, Coppola T, Sarret P, Vincent JP, "Structure, functional expression, and cerebral localization of the levocabastine-sensitive neurotensin/neuromedin $\mathrm{N}$ receptor from mouse brain," $\mathrm{J}$ Neurosci, 1996, 16, pp. 5613-5620.

[7] Mazella J, Zsürger N, Navarro V, Chabry J, Kaghad M, Caput D, Ferrara P, Vita N, Gully D, Maffrand JP, Vincent JP, “The $100-\mathrm{kDa}$ neurotensin receptor is gp95/sortilin, a non-G-protein-coupled receptor," J Biol Chem, 1998, 273, pp. 26273-26276.

[8] Kalafatakis K, Triantafyllou K, "Contribution of neurotensin in the immune and neuroendocrine modulation of normal and abnormal enteric function," Regul Pept, 2011, 170, pp. 7-17.

[9] Tyler-McMahon BM, Boules M, Richelson E, "Neurotensin: peptide for the next millennium," Regul Pept, 2000, 93, pp. 125-136.

[10] Luttinger D, King RA, Sheppard D, Strupp J, Nemeroff CB, Prange AJ Jr, "The effect of neurotensin on food consumption in the rat," Eur J Pharmacol, 1982, 81, pp. 499-503.

[11] Levine AS, Kneip J, Grace M, Morley JE, "Effect of centrally administered neurotensin on multiple feeding paradigms," Pharmacol Biochem Behav, 1983, 18, pp. 19-23.

[12] Cooke JH, Patterson M, Patel SR, Smith KL, Ghatei MA, Bloom SR, Murphy KG, "Peripheral and central administration of xenin and neurotensin suppress food intake in rodents," Obesity (Silver Spring), 2009, 17, pp. 1135-1143.

[13] Carraway R, Bhatnagar YM, "Isolation, structure and biologic activity of chicken intestinal neurotensin," Peptides, 1980, 1, pp. 167-174.

[14] Carraway RE, Ferris CF, "Isolation, biological and chemical characterization, and synthesis of a neurotensin-related hexapeptide from chicken intestine," J Biol Chem, 1983, 258, pp. $2475-2479$.

[15] Tanaka M, Nakao N, Yamamoto I, Tsushima N, Ohta Y, "Changes in expression levels of neurotensin precursor and receptor mRNA in chicken intestinal tissues and liver during late embryonic and early posthatching development," Poult Sci, 2013, 92, pp. 2765-2771.

[16] Numao M, Sudo H, Yamamoto I, Nakao N, Kaiya H, Miyazato M, Tsushima N, Tanaka M, "Molecular characterization of structure and tissue distribution of chicken neurotensin receptor," Gen Comp Endocrinol, 2011, 171, pp. 33-38. 
[17] Masuda K, Iwakoshi-Ukena E, Bessho Y, Taniuchi S, Maejima S, Shikano K, Kondo K, Furumitsu M, Ukena K, "Identification of neurotensin and LANT-6 and localization of mRNA encoding their precursor in the chicken brain," Zoolog Sci, 2014, 31, pp. 353-359.

[18] Williams G, Cai XJ, Elliott JC, Harrold JA, "Anabolic neuropeptides," Physiol Behav, 2004, 81, pp. 211-222.

[19] Kameda Y, Miura M, Nishimaki T, "Localization of neuropeptide $\mathrm{Y}$ mRNA and peptide in the chicken hypothalamus and their alterations after food deprivation, dehydration, and castration," J Comp Neurol, 2001, 436, pp. 376-388.

[20] Kuenzel WJ, Douglass LW, Davison BA, "Robust feeding following central administration of neuropeptide $Y$ or peptide YY in chicks, Gallus domesticus," Peptides, 1987, 8, pp. 823-828.

[21] Tachibana T, Sato M, Oikawa D, Takahashi H, Boswell T, Furuse M, "Intracerebroventricular injection of neuropeptide $\mathrm{Y}$ modifies carbohydrate and lipid metabolism in chicks," Regul Pept, 2006, 136, pp. 1-8.

[22] Saneyasu T, Honda K, Kamisoyama H, Ikura A, Nakayama Y, Hasegawa S, "Neuropeptide Y effect on food intake in broiler and layer chicks," Comp Biochem Physiol A Mol Integr Physiol, 2011, 159, pp. 422-426.

[23] National Research Council. "Guide for the care and use of laboratory animals," Washington, D.C: National Academy Press, 1996.

[24] Davis JL, Masuoka DT, Gerbrandt LK, Cherkin A, "Autoradiographic distribution of L-proline in chicks after intracerebral injection," Physiol Behav, 1979, 22, pp. 693-695.

[25] Furuse M, Ando R, Bungo T, Ao R, Shimojo M, Masuda Y, "Intracerebroventricular injection of orexins does not stimulate food intake in neonatal chicks," Br Poult Sci, 1999, 40, pp. 698-700.

[26] Saito ES, Kaiya H, Tachibana T, Tomonaga S, Denbow DM, Kangawa K, Furuse M, "Inhibitory effect of ghrelin on food intake is mediated by the corticotropin-releasing factor system in neonatal chicks," Regul Pept, 2005, 125, pp. 201-208.

[27] Ohinata K, Shimano T, Yamauchi R, Sakurada S, Yanai K, Yoshikawa M, "The anorectic effect of neurotensin is mediated via a histamine $\mathrm{H}_{1}$ receptor in mice," Peptides, 2004 , 25, pp. 2135-2138.

[28] Furuse M, "Central regulation of food intake in the neonatal chick," Animal Science Journal, 2002, 73, pp. 83-94.

[29] Vaccarino FJ, Bloom FE, Rivier J, Vale W, Koob GF, "Stimulation of food intake in rats by centrally administered hypothalamic growth hormone-releasing factor," Nature, 1985, 314, pp. 167-168.

[30] Vaccarino FJ, "Growth hormone-releasing factor and feeding. Behavioral evidence for direct central actions," Ann N Y Acad Sci, 1990, 579, pp. 227-232.

[31] Tachibana T, Sugimoto I, Ogino M, Sakirul Islam Khan M, Masuda K, Ukena K, Wang Y, "Central administration of chicken growth hormone-releasing hormone decreases food intake in chicks," Physiol Behav, 2015, 139, pp. 195-201.

[32] Lawrence CB, Celsi F, Brennand J, Luckman SM, "Alternative role for prolactin-releasing peptide in the regulation of food intake," Nat Neurosci, 2000, 3, pp. 645-646.

[33] Lawrence CB, Ellacott KL, Luckman SM, "PRL-releasing peptide reduces food intake and may mediate satiety signaling," Endocrinology, 2002, 143, pp. 360-367.

[34] Tachibana T, Moriyama S, Takahashi A, Tsukada A, Oda A, Takeuchi S, Sakamoto T, "Isolation and characterisation of prolactin-releasing peptide in chicks and its effect on prolactin release and feeding behavior," J Neuroendocrinol, 2011, 23, pp. $74-81$.

[35] Friedman JM, Halaas JL, "Leptin and the regulation of body weight in mammals," Nature, 1998, 395, pp. 763-770.

[36] Hâkansson ML, Brown H, Ghilardi N, Skoda RC, Meister B, "Leptin receptor immunoreactivity in chemically defined target neurons of the hypothalamus," J Neurosci, 1998, 18, pp. $559-572$.

[37] Sahu A, "Evidence suggesting that galanin (GAL), melanin-concentrating hormone $(\mathrm{MCH})$, neurotensin (NT), proopiomelanocortin (POMC) and neuropeptide Y (NPY) are targets of leptin signaling in the hypothalamus," Endocrinology, 1998, 139, pp. 795-798.

[38] Sahu A, Carraway RE, Wang YP, "Evidence that neurotensin mediates the central effect of leptin on food intake in rat," Brain Res, 2001, 888, pp. 343-347.

[39] Prokop JW, Schmidt C, Gasper D, Duff RJ, Milsted A, Ohkubo T, Ball HC, Shawkey MD, Mays HL Jr, Cogburn LA, Londraville RL, "Discovery of the elusive leptin in birds: identification of several 'missing links' in the evolution of leptin and its receptor," PLoS One, 2014, 9, e92751.

[40] Friedman-Einat M, Cogburn LA, Yosefi S, Hen G, Shinder D, Shirak A, Seroussi E, "Discovery and characterization of the first genuine avian leptin gene in the rock dove (Columba livia)," Endocrinology, 2014, 155, pp. 3376-3384.

[41] Huang G, Li J, Wang H, Lan X, Wang Y, "Discovery of a novel functional leptin protein (LEP) in zebra finches: evidence for the existence of an authentic avian leptin gene predominantly expressed in the brain and pituitary," Endocrinology, 2014, 155, pp. 3385-3396.

[42] Denbow DM, Meade S, Robertson A, McMurtry JP, Richards M, Ashwell C, "Leptin-induced decrease in food intake in chickens," Physiol Behav, 2000, 69, pp. 359-362.

[43] Bungo T, Shimojo M, Masuda Y, Tachibana T, Tanaka S, Sugahara K, Furuse M, "Intracerebroventricular administration of mouse leptin does not reduce food intake in the chicken," Brain Res, 1999, 817, pp. 196-198.

[44] Machidori H, Sakata T, Yoshimatsu H, Ookuma K, Fujimoto K, Kurokawa M, Yamatodani A, Wada H, "Zucker obese rats: defect in brain histamine control of feeding," Brain Res, 1992, 590, pp. 180-186.

[45] Lecklin A, Etu-Seppälä P, Stark H, Tuomisto L, "Effects of intracerebroventricularly infused histamine and selective $\mathrm{H}_{1}$, $\mathrm{H}_{2}$ and $\mathrm{H}_{3}$ agonists on food and water intake and urine flow in Wistar rats,” Brain Res, 1998, 793, pp. 279-288.

[46] Bessho Y, Iwakoshi-Ukena E, Tachibana T, Maejima S, Taniuchi S, Masuda K, Shikano K, Kondo K, Furumitsu M, Ukena K, "Characterization of an avian histidine decarboxylase and localization of histaminergic neurons in the chicken brain," Neurosci Lett, 2014, 578, pp. 106-110. 
[47] Kawakami S, Bungo T, Ohgushi A, Ando R, Shimojo M, Masuda Y, Denbow DM, Furuse M, "Brain-derived mast cells could mediate histamine-induced inhibition of food intake in neonatal chicks,” Brain Res, 2000, 857, pp. 313-316. 